\title{
SISTEM PAKAR PENILAIAN PENGUASAAN MATERI PELAJARAN BERBASIS WEBSITE DENGAN METODE BAYESIAN NETWORK (Studi Kasus di SMA Angkasa Yogyakarta)
}

\author{
Ni Kadek Ceryna Dewi, Anton Setiawan Honggowibowo, Dwi Nugraheny \\ Jurusan Teknik Informatika \\ Sekolah Tinggi Teknologi Adisutjipto Yogyakarta \\ informatika@stta.ac.id
}

\begin{abstract}
School is a place to study to implement the learning process. However, along with the development of teaching and learning technologies now can be done outside of school one of them with online media. Students at the school will usually feel a saturation point with the delivery of material in class with the different character of the teacher. For it is made a program that could provide a new learning method. Bayesian Network Methods is a Directed Acyclic Graph (DAG) and comes with a Conditional Probability Distribution Table (CPT) for each node. Bayesian Network Methods is running on the calculations to find the value of the results of the examination of the student. From the research that has been conducted on the " Expert System Assessment Mastery Of Subject Matter OfWebsite Based With Bayesian Network Method" of the obtained results for the average student's ability to answer every question with 5 topics there is $28.66 \%$ from $50 \%$.
\end{abstract}

Keywords: Expert System, Bayesian Network, DAG and CPT

\section{Pendahuluan}

Sekolah, merupakan tempat dimana seorang siswa medapatkan pendidikan mengenai banyak hal. Tidak hanya mengenai pendidikan tentang suatu mata pelajaran, tapi juga pendidikan budi pekerti dan pendidikan moral. Dikelas seorang guru mengajar dengan pola yang sama kepada semua siswanya, dan ini tentunya tidak efektif karena setiap siswa memiliki karakteristik pengetahuan yang berbeda.

Program ini menggunakan auto level dimana siswa akan diberikan soal sesuai dengan kemampuannya. Sistem pakar yang nantinya akan dibangun ini dibantu juga dengan metode Bayesian Network yang akan membantu dalam penarikan kesimpulan.

Bayesian Network adalah sebuah Direct Acyclic Graph (DAG) dan dilengkapi dengan Conditional Probability untuk sebuah pengamatan dan hipotesa, atau dengan menyisipkan logika berikutnya kedalam sebuah pola terintuisi. Pemikiran Bayesian menyediakan sebuah pendekatan probabilistik untuk mendapatkan suatu inference atau kesimpulan inference dalam sebuah Bayesian Network didapat dari hubungan setiap node yang terdapat pada struktur Bayesian tersebut. Untuk setiap perubahan yang terjadi dari sebuah node maka juga akan mempengaruhi nilai probabilitas dari node - node yang lain, yang secara langsung maupun tidak langsung berhubungan dengan node tersebut. Dengan menggunakan metode ini diharapkan akan mendapatkan suatu kesimpulan yang akurat mengenai besarnya bobot penguasaan materi suatu pelajaran dari seorang siswa. 
Dari uraian diatas, maka dapat diambil judul "Sistem Pakar Penilaian Penguasaan Materi Pelajaran Berbasis Website Dengan Metode Bayesian Network

\section{Landasan Teori}

\subsection{Sistem Pakar}

Sistem Pakar (expert system) adalah sistem yang berusaha untuk mengadopsi pengetahuan manusia ke komputer, agar komputer dapat menyelesaiakan masalah layakanya manusia atau ahli. Menurut Efraim Turban, konsep dasar sistem pakar mengandung keahlian, ahli, pengalihan keahlian, inferensi, aturan dan kemampuan menjelaskan. Sistem pakar dibangun agar dapat menyelsaikan masalah yang rumit layaknya pakar.

\subsection{Bayesian Network}

Metode Bayesian Network adalah sebuah Directed Acyclic Graph (DAG) dan dilengkapi dengan Conditional Probability distribution Table (CPT) untuk setiap nodenya. Setiap node merepresentasikan sebuah domain variable dan setiap arc/panah antar node merepresentasikan sebuah probabilistic dependency (Pearl, 1988). Secara umum, Bayesian Network dapat digunakan untuk menghitung probabilitas bersyarat dari suatu node dengan memberi nilai pada node lain yang berhubungan. Perhitungan nilai peluang pada suatu node dalam struktut Bayesian Network adalah dengan rumus sebagai berikut:

$$
P\left(x_{i}\right)=\sum_{j-i}^{m} P\left(x_{i}, y_{j}\right)
$$

Sebagai contoh, dengan struktur Bayesian Network sederhana pada gambar 2.1, maka rumus untuk menghitung peluang pada node $\mathrm{X}$ atau $\mathrm{P}(\mathrm{X}=$ True):

$$
\begin{aligned}
& P(X=\text { True })=\sum_{\alpha} \sum_{\beta} P(X=\text { True }) \mid Y=\alpha_{a} Z=\beta P(Y=\alpha) P(Z=\beta) \\
& \text { Dengan, } \begin{array}{l}
\alpha \in\{\text { True, False }\} \\
\beta \in\{\text { True, False }\}
\end{array}
\end{aligned}
$$

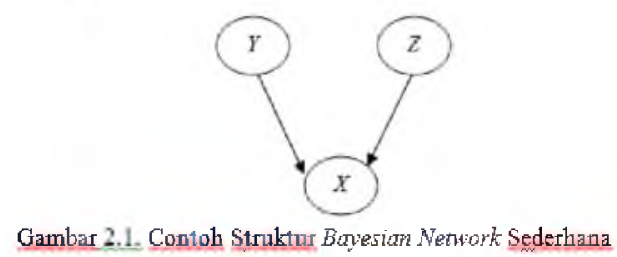

\section{Analisa dan Perancangan Sistem}

Perancangan sistem ini adalah komponen-komponen yang akan dibangun untuk membentuk atau merancang sistem yang akan dibuat nantinya. Perancangan sistem ini juga akan membantu supaya dalam pembuatan program tidak melenceng dari perancangan yang telah dibuat. 


\subsection{Flowchart}

Flowchart System adalah untaian simbol gambar (chart) yang menunjukkan aliran (flow) dari proses terhadap data, (Drs. Suarga, M.Sc., 2006). Dalam membuat suatu sistem yang sistematis, diperlukannya suatu Flowchart System untuk melihat proses aliran data yang ada dari awal sampai selesai.

Flowchart ini memperlihatkan proses perhitungan dari mulai proses penjawaban soal dimana pada proses pertama soal yang muncul pertama adalah soal dengan level 1 atau level paling mudah dimana pada level ini terdapat 15 soal yang harus dijawab. Setelah berhasil mengerjakan soal dengan hasil nilai lebih dari 16.875 maka akan dapat melanjutkan pada level 2 tapi jika tidak maka akan diminta untuk melakukan perbaikan pada level yang sama.

Pada level 2 dan 3 juga berlaku proses yang sama. Pada level 2 terdapat 20 soal yang harus dijawab, dan pada level 3 jumlah soal yang harus dijawab sebanyak 25 soal. Pada level 2 dan 3 nilai yang harus dicapai pada level 2 adalah 15.82 dan pada level 3 adalah 6.32. Setelah berhasil mencapai pada level 3 maka akan diketahui total peroleh nilai secara keseluruhan. User juga dapat mencetak hasil nilai yang diperoleh, begitu juga dengan guru bisa mencetak hasil dari ujian user telah melakukan ujian.

Adapun flowchart system pada aplikasi "Sistem Pakar Penilaian Penguasaan Materi Pelajaran Berbasis Website Dengan Metode Bayesian Network" dapat dilihat pada gambar 1.

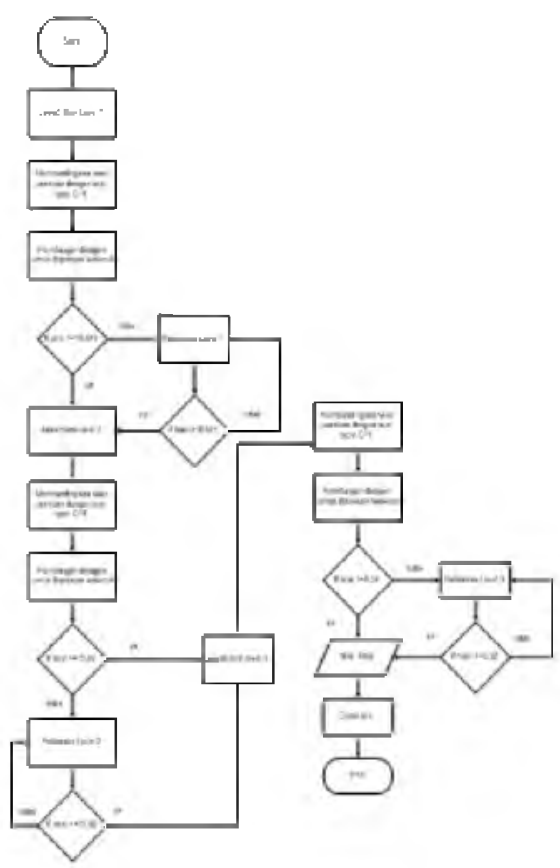

Gambar 1 Flowchart system

\subsection{Perancangan Diagram Alir Data}

Diagram Alir Data atau DAD adalah suatu diagram yang menggunakan notasinotasi untuk menggambarkan arus dari data sistem, yang penggunaannya sangat membantu untuk memahami sistem secara logika, tersruktur dan jelas. 


\subsubsection{Diagram Konteks}

Diagram ini adalah diagram level tertinggi dari DAD yang menggambarkan hubungan sistem dengan lingkungan luarnya. Pada gambar 2 siswa selaku user harus menginputkan data berupa username dan password sebelum masuk ke program dan melakukan ujian. Sementara guru bisa melakukan input soal dan nilai. Setelah melakukan ujian siswa akan mendapatkan outpu berupa nilai hasil ujian. Begitu juga dengan guru yang akan mendapatkan hasil ujian seluruh siswa yang telah mengikuti ujian.

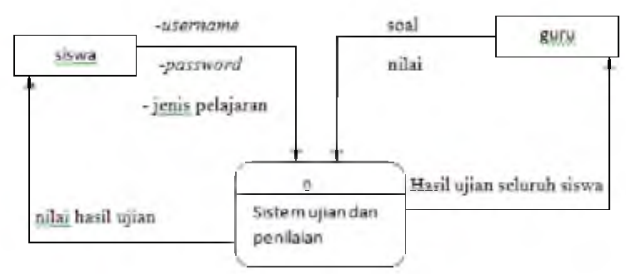

Gambar 2 Diagram konteks

\subsubsection{DAD Level 1}

Diagram level 1 adalah diagram yang menggambarkan proses dari data flow diagram. Pada gambar 3 terdapat 3 proses yang berjalan yaitu proses pengerjaan soal, penginputan soal dan jawaban dan proses perhitungan.

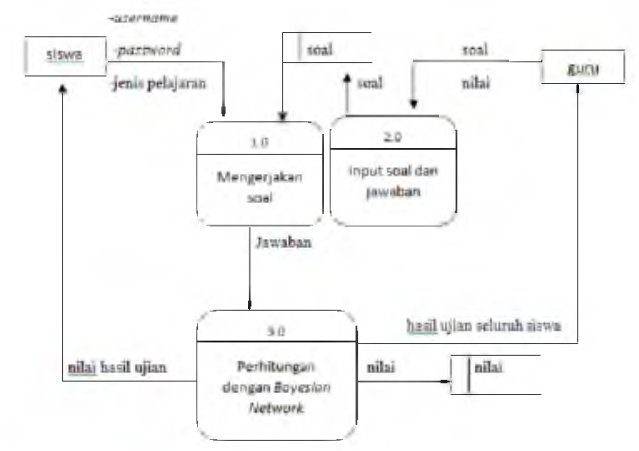

Gambar 3 DAD level 1

\subsubsection{DAD Level 2}

Setiap sub proses yang ada pada level 1 dapat diturunkan lagi secara lebih terperinci menjadi DAD baru lagi. Adapun dalam level ini proses tersebut akan dirinci lagi menjadi dua sub proses yaitu, proses membandingkan jawaban dengan tabel CPT, dan proses perhitungan dengan rumus Bayesian Network.

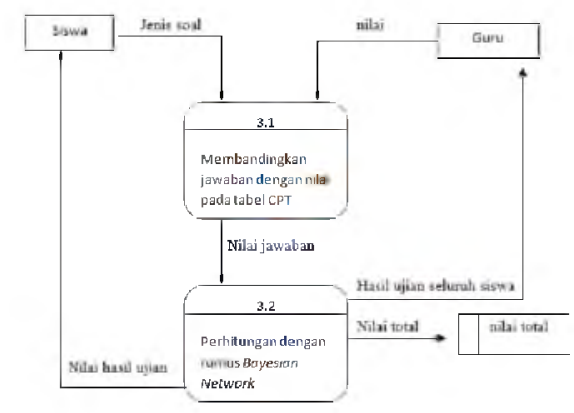

Gambar 4 DAD leve1 2 


\section{Implementasi}

Halaman depan ini, adalah halaman yang muncul pertama kali saat program dijalankan. Pada halaman ini terdapat Menu Home, media untuk Login dan Menu Daftar User. Adapun tampilannya seperti pada gambar 5 .

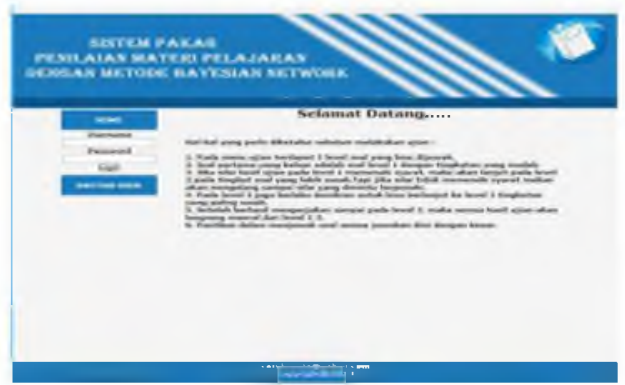

Gambar 5 Tampilan awal

Berikut ini adalah tampilan untuk mendaftar jika user belum memiliki username dan password.

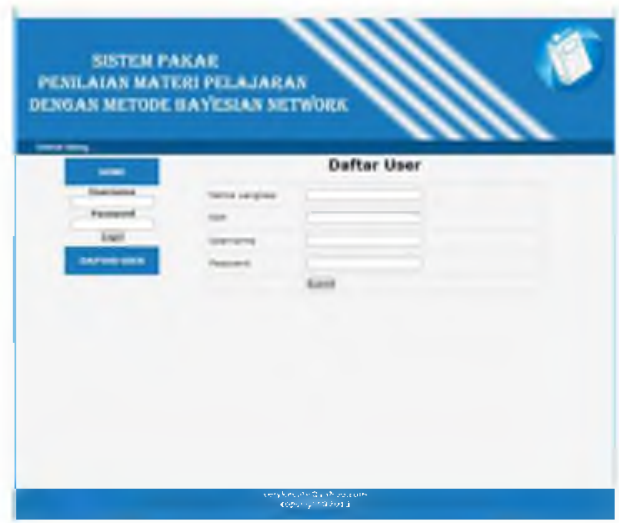

Gambar 6 Daftar $u$ ser

Berikut ini adalah tampilan awal jika user akan melakukan ujian. Terdapat data user serta mata pelajaran yang akan diujiankan.

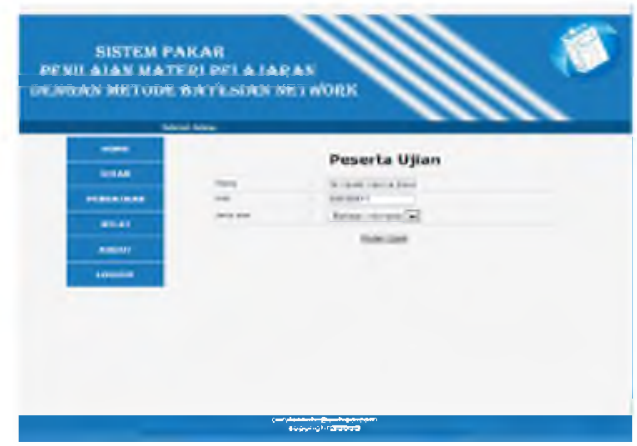

Gambar 7 Ujian

Setelah user menekan tombol Mulai Ujian maka user akan masuk pada tampilan soal ujian seperti berikut ini. 


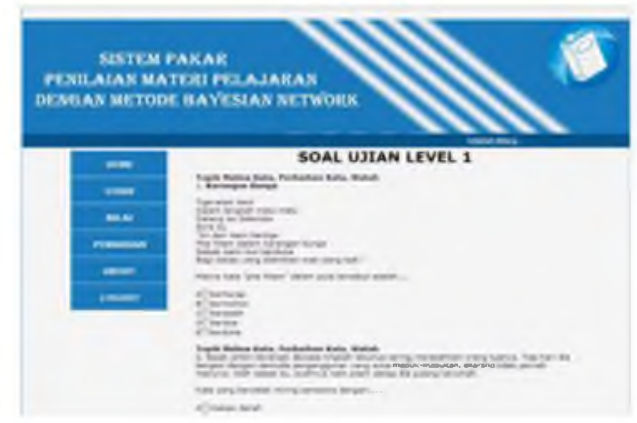

Gambar 8 Soal ujian

Berikut ini adalah tampilan hasil ujian yang diperoleh user setelah melakukan ujian. Jika user berhasil mencapai nilai yang ditentukan maka user akan lanjut kelevel selanjutnya.

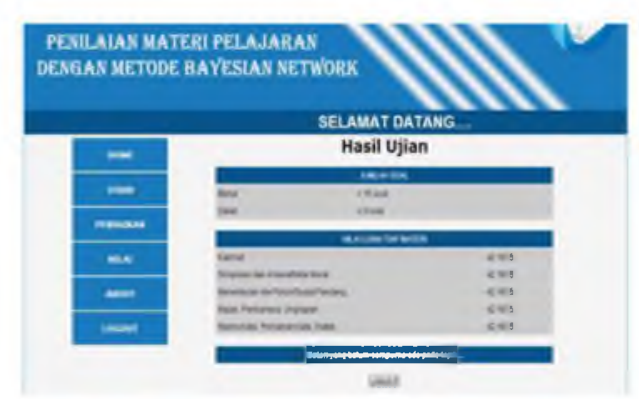

Gambar 9 Hasil ujian

Perhitungan untuk memperoleh nilai hasil ujian tersebut dilakukan dengan menggunakan metode Bayesian Network pertama harus dibuat dulu bagan pembagian materi atau topik dari mata pelajaran Bahasa Indonesia seperti pada gambar berikut ini.

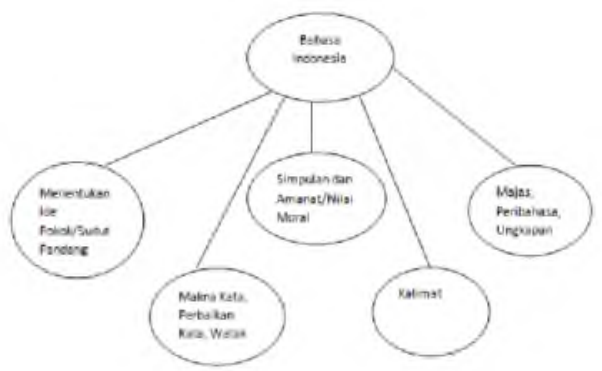

Gambar 10 Bagan pembagian topik Bahasa Indonesia

Setelah bagan terbentuk barulah dibuat struktur dari Bayesian Network seperti berikut ini :

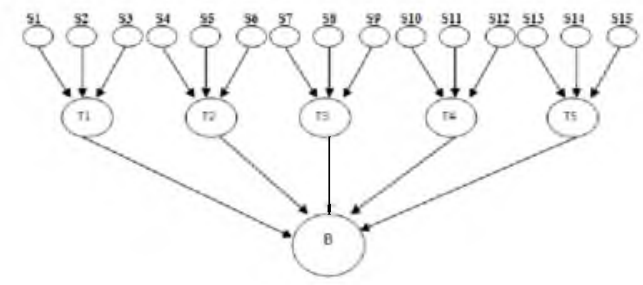

Gambar 11 Struktur baysian

Keterangan :

$\mathrm{B} \quad$ = Pelajaran Bahasa Indonesia 
T1-T5 = Mewakili setiap topik

S1-S15 = Soal 1-15 pada level 1

S1-S20 = Soal 1-20 pada level 2

S1-S25 = Soal 1-25 pada level 3

Setelah struktur terbentuk baru ditentukan Conditional Probability Table (CPT) seperti berikut merupakan tabel berikut:

Tabel CPT level 1

\begin{tabular}{|c|c|c|}
\hline Node & $\mathrm{T}=\mathrm{True} . \mathrm{F}=\mathrm{F}$ alse. $\mathrm{P}=$ Probabilitas & Probabritas \\
\hline \multirow[t]{8}{*}{ T1 } & $\mathrm{P}(\mathrm{T} 1 \mid \mathrm{S} 1=\mathrm{T}: \mathrm{S} 2=\mathrm{T}: \mathrm{S} 3=\mathrm{T})$ & 1 \\
\hline & $\mathrm{P}(\mathrm{T} 1 \mid \mathrm{S} 1=\mathrm{T}: \mathrm{S} 2=\mathrm{T}: \mathrm{S} 3=\mathrm{F})$ & 0.6 \\
\hline & $\mathrm{P}(\mathrm{T} 1 \mid \mathrm{S} 1=\mathrm{T} ; \mathbf{S 2}=\mathrm{F} ; \mathrm{S3}=\mathrm{T})$ & 0.6 \\
\hline & $\mathrm{P}(\mathrm{T} 1 \mid \mathrm{S} 1=\mathrm{T}: \mathrm{S} 2=\mathrm{F}, \mathrm{S3}=\mathrm{F})$ & 0.3 \\
\hline & $\mathrm{P}(\mathrm{T} 1 \mid \mathrm{S} 1=\mathrm{F}, \mathrm{S2}=\mathrm{T}, \mathrm{S3}=\mathrm{T})$ & 0.6 \\
\hline & $\mathrm{P}(\mathrm{T} 1 \mid \mathrm{S} 1=\mathrm{F}, \mathrm{S} 2=\mathrm{T}, \mathrm{S} 3=\mathrm{F})$ & 0.3 \\
\hline & $\mathrm{P}(\mathrm{Tl} \mid \mathrm{S} 1=\bar{F}, \mathrm{~S} 2=\bar{F}, \mathrm{~S} 3=\mathrm{T})$ & 0.3 \\
\hline & $\mathrm{P}(\mathrm{T} 1 \mid \mathrm{S} 1=\mathrm{F}, \mathrm{S} 2=\mathrm{F}, \mathrm{S3}=\mathrm{F})$ & 0.01 \\
\hline \multirow[t]{8}{*}{$\mathrm{T} 2$} & $\mathrm{P}(\mathrm{T} 2 \mid \mathrm{S} 4=\mathrm{T}: \mathrm{S} 5=\mathrm{T}: \mathrm{S} 6-\mathrm{T})$ & 1 \\
\hline & $\mathrm{P}(\mathrm{T} 2 \mid \mathrm{S} 4=\mathrm{T}, \mathrm{S} 5=\mathrm{T}, \mathrm{S} 6=\mathrm{F})$ & 0.6 \\
\hline & $\mathrm{P}(\mathrm{T} 2 \mid \mathbf{S} \mathbf{4}=\mathbf{T}, \mathbf{S} 5=\mathrm{F}, \mathrm{S} 6=\mathrm{T})$ & 0.6 \\
\hline & $\mathrm{P}(\mathrm{T} 2 \mid \mathbf{S} 4=\mathbf{T}, \mathbf{S} 5=\mathrm{F}, \mathbf{S 6}=\mathrm{F})$ & 0.3 \\
\hline & $\mathrm{P}(\mathrm{T} 2 \mid \mathrm{S4}=\mathrm{F}, \mathrm{S} 5=\mathrm{T}, \mathrm{S} 6=\mathrm{T})$ & 0.6 \\
\hline & $\mathrm{P}(\mathrm{T} 2 \mid \mathrm{S} 4=\mathrm{F} . \mathrm{S} 5=\mathrm{T}, \mathrm{S} 6=\mathrm{F})$ & 0.3 \\
\hline & $\mathbf{P}(\mathbf{T} 2 \mid \mathbf{S} 4=\mathrm{F}, \mathbf{S} 5=\mathrm{F}, \mathrm{S} 6=\mathrm{T})$ & 0.3 \\
\hline & $\mathrm{P}(\mathrm{T} 2 \mid \mathrm{S} 1-\mathrm{F}, \mathrm{S} 5=\mathrm{F}, \mathrm{S} 6-\mathrm{F})$ & 0.01 \\
\hline \multirow[t]{8}{*}{$\mathrm{TH}$} & $\mathbf{P}(\mathrm{T} 4 \mid \mathrm{S} 0.01=\mathrm{T} ; \mathrm{S} 1 \mathrm{l}=\mathrm{T}, \mathrm{S} 12=\mathrm{T})$ & 1 \\
\hline & $\mathbf{P}(\mathrm{T} 4 \mid \mathrm{S} 0.01=\mathrm{T} ; \mathrm{S} 11=\mathrm{T} ; \mathrm{S} 1 \mathbf{2}=\mathbf{F})$ & 0.6 \\
\hline & $\mathbf{P ( T 4} \mid \mathbf{S} 0.01=T ; S 11=F . S 12=T)$ & 0.6 \\
\hline & $\mathbf{P}(\mathrm{T} 4 \mid \mathrm{S} 0.01=\mathrm{T} ; \mathrm{S} 11=\mathrm{F} \cdot \mathrm{S} 12=\mathrm{F})$ & 0.3 \\
\hline & $P(\mathbb{T} 4 \mid \mathrm{S} 0.01=F, \$ 11=T, \$ 12=T)$ & 0.6 \\
\hline & $\mathbf{P}(\mathrm{T} 4 \mid \mathbf{S} 0.01=\mathrm{F}, \mathrm{S} 11=\mathrm{T}, \mathbf{S} 12=\mathrm{F})$ & 0.3 \\
\hline & $\mathrm{P}(\mathrm{T} 4 \mid \mathrm{S} 0.01=\mathrm{F}, \mathrm{S} 11=\mathrm{F}, \mathrm{S} 12-\mathrm{T})$ & 0.3 \\
\hline & $\mathrm{P}(\mathrm{T} 4 \mid$ S0.01-F. S11-F. S12=F) & 0.01 \\
\hline \multirow[t]{8}{*}{$\mathrm{T} 3$} & $\mathrm{P}\left(\mathrm{T} / \mathrm{S} \mid \mathrm{S} 1 \mathrm{z}=\mathrm{T}, \mathrm{S}_{14}=\mathrm{T}, \mathrm{S} / \mathrm{S}=\mathrm{T}\right)$ & 1 \\
\hline & $\mathrm{P}(\mathrm{T} 5 \mid \mathrm{S} 13=\mathrm{T}, \mathrm{S} 14=\mathrm{T}, \mathrm{S} 15=\mathrm{F})$ & 0.6 \\
\hline & $\mathrm{P}(\mathrm{T} 5 \mid \mathrm{S} 13=\mathrm{T}, \mathrm{S} 14=\mathrm{F}: \mathrm{S} 15=\mathrm{T})$ & 0.6 \\
\hline & $\mathrm{P}(\mathrm{T} \xi|\mathrm{S} 13=\mathrm{T}, \mathrm{S}| \mathrm{A}=\mathrm{F}, \mathrm{S} 15=\mathrm{F})$ & 0.3 \\
\hline & $\mathrm{P}(\mathrm{T}\} \mid \mathrm{S} 13=\mathrm{F}, \mathrm{S} 14=\mathrm{T}, \mathrm{S} 15=\mathrm{T})$ & 0.6 \\
\hline & $\mathrm{P}\left(\mathrm{T} 5 \mid \mathrm{s} 13=\mathrm{F}, \$ 14=\mathrm{T}_{\mathrm{s}}, \$ 15=\mathrm{F}\right)$ & 0.3 \\
\hline & $\mathrm{P}(\mathrm{T} S \mid \mathrm{S} 13=\mathrm{F}, \mathrm{S} 1 \mathrm{~A}=\mathrm{F}, \mathrm{S} 15=\mathrm{T})$ & 0.3 \\
\hline & $\mathrm{P}(\mathrm{T} S \mid \mathrm{S} \perp 3=\mathrm{F}, \mathrm{S} 1 \mathrm{~A}=\mathrm{F}, \mathrm{S} 15=\mathrm{T})$ & 0.01 \\
\hline
\end{tabular}

Berikut adalah contoh perhitungan untuk soal pada level 1:

Pada level 1 masing - masing topik memiliki 3 soal dan dalam satu level terdapat 5 topik, jadi total soal ada 15. Pada kasus ini masing - masing soal pada semua topik, untuk jawaban benar diberikan nilai 0.75 dan untuk jawaban salah diberikan nilai 0.5. Perhitungan yang akan dilakukan oleh metode Bayesian network ini adalah menghitung nilai per topik dengan satu topiknya terdapat 3 soal. Misalkan saja topik $1=\mathrm{T} 1$, soal $1=S 1$, soal $2=S 2$ dan soal $3=S 3$. Jika user bisa menjawab dengan jawaban benar atau true pada ketiga soal pada T1 maka perhitungannya adalah:

$\mathrm{P}(\mathrm{T} 1)=\mathrm{P}(\mathrm{T} 1 \mid \mathrm{S} 1=\mathrm{T}, \mathrm{S} 2=\mathrm{T}, \mathrm{S} 3=\mathrm{T}) \mathrm{P}(\mathrm{S} 1) \mathrm{P}(\mathrm{S} 2) \mathrm{P}(\mathrm{S} 3)$

$=(1 * 0.75 * 0.75 * 0.75) * 100=42.18$

Jadi nilai yang diperoleh untuk jawaban $\mathrm{S1}=\mathrm{T}, \mathrm{S} 2=\mathrm{T}, \mathrm{S} 3=\mathrm{T}$ adalah 42.18 
Nilai 1 diperoleh dari tabel CPT disesuaikan dengan jawaban dari user. Pada level 1 ini user harus memperoleh nilai minimal 16.875 dengan perkiraan jawaban benar S1=T, S2=F, S3=T maka perhitungannya adalah:

$$
\begin{aligned}
& P(T 1)=P(T 1 \mid S 1=T, S 2=F, S 3=T) P(S 1) P(S 2) P(S 3) \\
& =\left(0.6^{*} 0.75^{*} 0.5^{*} 0.75\right)^{*} 100=16.875
\end{aligned}
$$

Jadi nilai yang diperoleh untuk jawaban S1=T, S2=F, S3=T adalah 16.875

Dan jika user salah dalam menjawab setiap soal dalam topik tersebut maka perhitungannya adalah :

$$
\begin{aligned}
& P(T 1)=P(T 1 \mid S 1=F, S 2=F, S 3=F) P(S 1) P(S 2) P(S 3) \\
& =\left(0.01 * 0.5^{*} 0.5^{*} 0.5\right)^{*} 100=0.125
\end{aligned}
$$

Dari 30 siswa yang melaksanakan ujian tidak ada yang bisa masuk ke level 2 ataupun level 3. Siswa hanya mampu mengerjakan ujian pada level 1. Pada level 1 ini bisa dilihat persentase perolehan dari masing-masing topik. Untuk bisa lanjut kelevel selanjutnya siswa harus memperoleh nilai minimal 16.875 untuk masing-masing topiknya. Jika salah satu topik masih kurang dari 16.875 maka siswa tetap tidak bisa naik level dan tetap berada pada level 1 . Adapun hasil yang bisa dianalisa bisa dilihat dari gambar diagram dan tabel berikut ini.

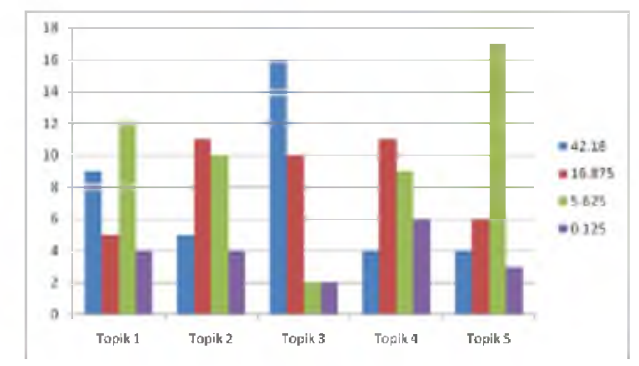

$$
\begin{array}{ll}
\text { Keterangan: } & \\
\text { 0-18 } & =\text { Jumlah User } \\
\text { Topik } 1 & =\text { Menentukan Ide Pokok Sudut Pandang } \\
\text { Topik } 2 & =\text { Simpulan dan Amanat Nilai Moral } \\
\text { Topik } 3 & =\text { Makna Kata, Perbaikan Kata: Watak } \\
\text { Topik } 4 & =\text { Kalimat } \\
\text { Topik } 5 & =\text { Majas: Peribahasa: Ungkapan }
\end{array}
$$

Dari digram diatas bisa dihitung presentase perolehan nilai dari masing - masing topik. Dari diagram tersebut bisa dilihat jumlah user yang bisa mencapai nilai standar yang ditentukan yaitu 16.875 tidak ada yang mencapai setengahnya dari user yang mengikuti ujian. Nilai rata-rata $=(16.66 \%+36.66 \%+33.33 \%+36.66 \%+20 \%) / 5$

$$
=28.66 \%
$$

Jadi, dari perolehan tersebut bisa ditarik kesimpulan untuk rata-rata kemampuan siswa dalam menjawab setiap soal dengan 5 topik yang ada adalah $28.66 \%$. 


\section{Kesimpulan}

Kesimpulan yang diperoleh dari penelitian ini adalah :

1. Metode Bayesian Network sangat membantu dalam pencarian hasil perhitungan program “Sistem Pakar Penilaian Penguasaan Materi Pelajaran Berbasis Website Dengan Metode Bayesian Network".

2. Dari hasil uji coba yang telah dilaksanakan user hanya mencapai ujian pada level 1 dengan perolehan nilai tiap topiknya yang bervariasi dengan presentase keseluruhan untuk topik Menentukan Ide Pokok/Sudut Pandang $=16.66 \%$, Simpulan dan Amanat/Nilai Moral $=36.66 \%$, Makna Kata, Perbaikan Kata, Watak $=33.33 \%$, Kalimat $=36.66 \%$, Majas, Peribahasa, Ungkapan $=20 \%$.

3. Dari hasil penelitian yang telah dilaksanakan maka diperoleh hasil untuk rata-rata kemampuan siswa dalam menjawab setiap soal dengan 5 topik yang ada adalah $28.66 \%$ dari $50 \%$.

Program aplikasi ini masih dapat dikembangkan lagi menjadi sebuah aplikasi yang lebih kompleks lagi, antara lain:

1. Program ini bisa dikembangkan dengan menambahkan media - media pembelajaran, tidak terbatas hanya pada menjawab soal, program ini bisa dikembangkan menjadi pembalajaran berbasis multimedia.

2. Program ini juga bisa dikembangkan tidak hanya terbatas untuk tingkat Sekolah Menengah Atas (SMA), tapi dapat dikembangkan untuk Sekolah Menengah Pertama (SMP), Sekolah Dasar (SD).

\section{Daftar Pustaka}

Kendall \& Kendall., 2006, Analisa dan Perancangan Sistem, Indeks, Jakarta

Kjaerulff, Uffie B. dan Madsen, Anders L., 2008, Bayesian Network and Influence Diagrams, A Guide to Construction and Analysis, Springer

Kung, Tan Ai dan Mohamad, M.S., 2012, Using Bayesian Networks to Construct Gene Regulatory Networks from Microarray Data, Jurnal Teknologi Vol.1 April 2012 ISSN : 0127-9696, Universiti Teknologi Malaysia, Johor Bahru

Nugroho, Bunafit, 2008, Membuat Aplikasi Sistem Pakar Dengan PHP dan Editor Dreamweaver, Gava Media, Yogyakarta

Roselina,Y.N, dkk., 2012, Aplikasi Diagnosa Penyakit Asma Menggunakan Bayesian Network Berbasis Web, Jurnal Teknik Informatika Vol.1 September 2012, Politeknik Caltex Riau, Pekanbaru

Suarga., 2006, Algoritma Pemrograman, CV. Andi Offset, Yogyakarta

Subagyo, Pangestu., 2011, Statistika Terapan, BPFE-Yogyakarta, Yogyakarta

Syafii, M., 2005, Panduan Membuat Aplikasi Database dengan PHP 5, CV. Andi Offset, Yogyakarta 
Masih Musliatun, Haruno Sajati, Yuliani Indrianingsih 